\title{
PENGARUH KOMITMEN, KEMAMPUAN DAN MOTIVASI TERHADAP PRESTASI KERJA APARAT KANTOR DESA SELAT AKAR KECAMATAN TASIK PUTRI PUYU
}

\author{
Arifudin $^{1}$ \\ Mei Indrawati ${ }^{2}$ \\ C. Sri Hartati ${ }^{3}$ \\ Program Magister Manajemen Universitas Wijaya Putra Surabaya ${ }^{1,2,3}$ \\ email: ariffudin99on@gmail.com
}

\begin{abstract}
The target of this research is to provide an overview and analysis of the impact between commitment, ability and motivation on the work performance of the Selat Akar Village Office Apparatus, Tasik Putri Puyu District. The research approach is included in the quantitative research approach. The population is 31 officers from Selat Akar Village Office, Tasik Putri Puyu District and the number of samples is 30 people using census sampling technique. The method of collecting data is using questionnaires and documentation. The data analysis technique in this study used multiple linear regression analysis. The findings in the research found that the commitment and work ability of the officers were in fairly good condition, while the motivation and work performance of the officers at the Selat Akar Village Office were in good condition. There is no significant impact between ability on work performance while there is a significant impact between ability or motivation on work performance of the Selat Akar Village Office Apparatus, Tasik Putri Puyu District.
\end{abstract}

Keywords: commitment, ability, motivation and achievement.

\section{PENDAHULUAN}

Pada abad ke-21 ini, setiap organisasi dituntut untuk cepat tanggap terhadap perubahan kebutuhan masyarakat agar dapat bersaing dan tetap unggul. Oleh karena itu pelayanan organisasi harus berfokus pada keinginan warga negara yang berpandangan bukan hanya untuk rasa puas melainkan pada pandangan akan nilai sehingga sumber daya manusia yang terdapat kemampuan dan berkompetensi unggul menjadi satu dari banyak hal yang berguna untuk menambah daya kerja suatu instansi yang dinaunginya selaras pada target serta tujuan perusahaan ataupun organisasi yang ada (Prasetyo, et al., 2021). Untuk mampu menghasilkan keluaran yang selaras pada visi serta misi perusahaan atau instansi perlu adanya perhatian pada peningkatan prestasi kerja sumber daya manusia atau pegawai (Utari, et al., 2021). Peningkatan prestasi kerja keryawan memiliki potensi yang mampu menaikan prestasi kerja sekumpulan karyawab serta menaikan prestasi kerja pada keseluruhan sekumpulan karyawan mampu memicu peningkatan prestasi kerja perusahaan atau instansi yang kemudian berperan serta pada akselerasi penggapaian 
target serta sasaran yang sebelumnya sudah ditetapkan (Utari, et al., 2020).

$\begin{array}{lcr}\text { Karyawan } & \text { yang } & \text { memiliki } \\ \text { komitmen } & \text { besar } & \text { kepada } \\ \text { perusahaannya } & \text { mampu } & \text { memicu }\end{array}$
prestasi kerja perusahaan yang telah ditargetkan, angka ketidakhadiran menurun, keloyalan pegawai, serta hal lainnya. Temuan riset Sukmana dan Adinegara (2018:277) menunjukkan jika berkomitmen organisasional berdampak pada hasil kinerja pegawai. Begitu juga termuan riset Syukriadi et. al (2019:1) yang menunjukkan bahwa berkomitmen suatu perusahaan berdampak pada hasil akan kinerja pada Kemenag di Kabupaten Bulukumba. Berbeda dengan hasil penelitian yang dilakukan Usman (2019:140) yang menunjukkan jika faktor komitmen perusahaan memberikan bukti berdampak positif namun tidak signifikan pada faktor prestasi bekerja.

Hal yang dapat memberikan dampak pencapaian capaian kinerja merupakan keahlian kerja pegawai. Melalui sisi psikologi, kemampuan (ability) karyawan yang berupa taraf kecerdasan (IQ) serta realisasi antara pikiran dan kenyataan (knowledge + skill) (Mangkunegara, 2011:67). Keterampilan bekerja adalah implementasi pengetahuan bidang kemudian keterampilan dan teknologi yang menunjang keberlangsungan serta kepraktisan pada saat menjalankan kerja serta dapat menopang tiap ubahan yang dilaksanakan manajerial.

Individu karyawan yang memiliki motivasi, karyawan yang dimaksud dengan sepenuh daya akan melakukan kerja keras pada kerjanya secara maksimal demi pencapaian perusahaan. Kinerja maksimal yang dilaksanakan berdasarkan atas motivasi maupun dorongan dapat memberikan dampak akan suatu rasa puas bagi individu karyawan saat melaksanakan kerjaannya (Utari, et al., 2020). Rasa puas dalam bekerja serta motivasi bekerja memiliki kaitan yang erat pada komitmen perusahaan karyawan (Mathiew and Jones dalam Syukriyadi et. al, 2019:4).

Dalam rangka meningkatkan pretasi kerja Aparat di Kantor Desa Selat Akar Kecamatan Tasik Putri Puyu, maka diperlukan komitmen, kemampuan dan motivasi. Berdasarkan hal yang diungkapkan, mendorong peneliti berminat untuk melaksanakan riset dengan tema "Pengaruh Komitmen, Kemampuan dan Motivasi terhadap Prestasi Kerja Aparat Kantor Desa Selat Akar Kecamatan Tasik Putri Puyu".

\section{TINJAUAN PUSTAKA Prestasi kerja}

Prestasi bekerja adalah capaian kinerja individu pegawai dalam masa yang telah ditentukan sebelumnya yang diperbandingkan dengan banyak hal yang mempengaruhi seperti aturan dasar, sasaran/ target serta patokan yang sebelumnya sudah ditetapkan, disepakati bersama terlebih dahulu. Menurut Hasibuan (2016:94) mengatakan jika, prestasi bekerja merupakan suatu capaian kinerja individu saat menjalankan kewajiban serta tugasnya yang telah diberikan yang berdasar pada pengalaman, cakap serta niatnya akan menjalankan pekerjaan. Kemudian (Rivai, 2015: 309) mengungkapkan jika hasil kinerja adalah salah satu fungsi dari kemampuan dan motivasi. 


\section{Komitmen}

Robbins et al. (2015:100) mengungkapkan jika komitmen dalam organisasi adalah satu kondisi dimana pegawai yang telah memilih perusahaan yang ada yang kemudian memiliki visi misi serta rasa ingin yang sama dengan perusahaannya yakni untuk mempertahankan diri. Komitmen pada suatu organisasi merupakan tindakan yang menggambarkan sisi loyal karyawan pada suatu perusahaan serta tahapantahapan selanjutnya yang mana individu tersebut mempu mencurahkan perhatian dengan terarah (Luthans, 2012:249).

Komitmen dalam perusahaan adalah rasa percaya pada poin-poin perusahhan, rasa siap sedia untuk mengusahakan hal terbaik untuk kepentingan perusahaan serta keinginan untuk selalu menjadi bagian dari perusahaan tersebut yang kemudian diungkapkan individu terhadap perusahaannya. Komutmen pada perusahaan mmiliki peran utama pada proses terciptanya gambaran dari perusahaan, dengan komitmen perusahaan karyawan dapat memiliki kompetensi yang dapat dinilai melalui prestasi dalam bekerja yang tercapai. Robbins (2015) mengemukakan komitmen dilihat sebagai dalah satu pandangan nilai-nilai pada perusahaan yang menggambarkan karyawan begitu memperhatikan serta menjadikan kerjanya sebagai hal yang utama serta perusahaannya. Karyawan dapat melakukan usaha dalam memberikan semua tenaga yang mampu dilakukan sebagai upaya mewujudkan tujuan perusahaan.

\section{Kemampuan}

Hasibuan

(2017:94), menyatakan jika kemampuan bekerja merupakan merupakan suatu capaian kinerja individu saat menjalankan kewajiban serta tugasnya yang telah diberikan yang berdasar pada pengalaman, cakap serta niatnya akan menjalankan pekerjaan. Kemudian pendapat Mangkunegara (2017:67) dari sisi psikologis, kemampuan dapat diuraikan atas kemampuan inteligensi (IQ) dan kenyataan, maksud dari ungkapan tersebut adalah pegawai dengan IQ yang lebih tinggi dari biasanya yang kemudian ditunjang dengan pendidikan yang sesuai untuk pekerjaannya kemudian memiliki kecakapan erta keterampilan dalam melaksanakan kerjanya, menjadikan karyawan tersebut lebih mudah dalam menggapai prestasi kerjanya. Kemampuan merupakan sifat yang terdapat sejak manusia dilahirkan dan dapat dipergunakan individu dalam menjalankan pekerjaannya (Gibson, 2017: 77).

Kemampuan merupakan jangkauan pada diri karyawan dalam melaksanakan berbagai pekerjaan pada suatu perusahaan. Kemampuan bisa berwujud minat serta bakat yang terdapat dalam diri karyawan, yang kemudian hal tersebut dapat dijadikan individu sebagai alat untuk menyelesaikan serta menjalankan kerja secara optimal hingga didapatkan hasil yang optimal. Ungkapan Nawawi (2016) bahwa keinginan dari pimpinan perusahaan pada taraf kinerja pegawainya akan difokuskan pada hasil kerja yang telah maksimal ataupun tidak. Sehingga relasi pada kemampuan bekerja pegawai dengan prestasi secara teoretis bisa dikatakan bahwa individu pegawai yang bekerja secara maksimal akan diusahakan oleh pemimpinannya untuk menciptakan perasaan dari pegawainya yang 
menyukai dan mencintai bidang kerjanya.

\section{Motivasi}

Notoatmodjo

(2015:114)

menjelaskan bahwa motivasi

bersumber dari bahasa latin makna motivasi (motivation) bersumber pada bahasa latin, yakni "movere" yang memiliki makna "menggerakan" (to move) (Robbins, 2015:47). Motivasi adalah segala sesuatu yang memberikan energi pada individu yang kemudian menghasilkan tenaga, tujuan serta mempu memberikan dampak pada sikap individu tersebut. Motivasi pada suatu manajerial secara umum dapat dipergunakan pada SDM dan khususnya untuk parabawahan. Hasibuan (2017:23) makna dari motivasi yakni mengenai langkahlangkah untuk mengarahkan keinginan bekerja karyawan, sehingga mereka secara rela melakukan kerja keras dengan usaha penuh, serta secara terampil dalam menggapai target dari perusahaan.

\section{Hipotesis}

$\mathrm{H}_{1}$ : Terdapat pengaruh yang signifikan antara komitmen

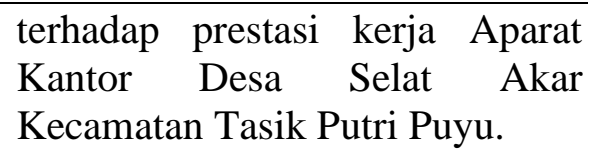

$\mathrm{H}_{2}$ : Terdapat pengaruh yang signifikan antara kemampuan terhadap prestasi kerja Aparat Kantor Desa Selat Akar Kecamatan Tasik Putri Puyu.

$\mathrm{H}_{3}$ : Terdapat pengaruh yang signifikan antara motivasi terhadap prestasi kerja Aparat Kantor Desa Selat Akar Kecamatan Tasik Putri Puyu.

Prestasi kerja karyawan merupakan gabungan dari tiga hal antara lain perangai, kemampuan serta intensi individu dalam bekerja, transparansi pekerjaan serta jelasnya kedudukan dalam bekerja serta motivasi dalam bekerja (Sutrisno, 2017). Sehingga berdasarkan teori yang dijelaskan di atas dapat digambarkan mengenai kerangka konsep penelitian yang akan dilaksanakan selanjutnya:

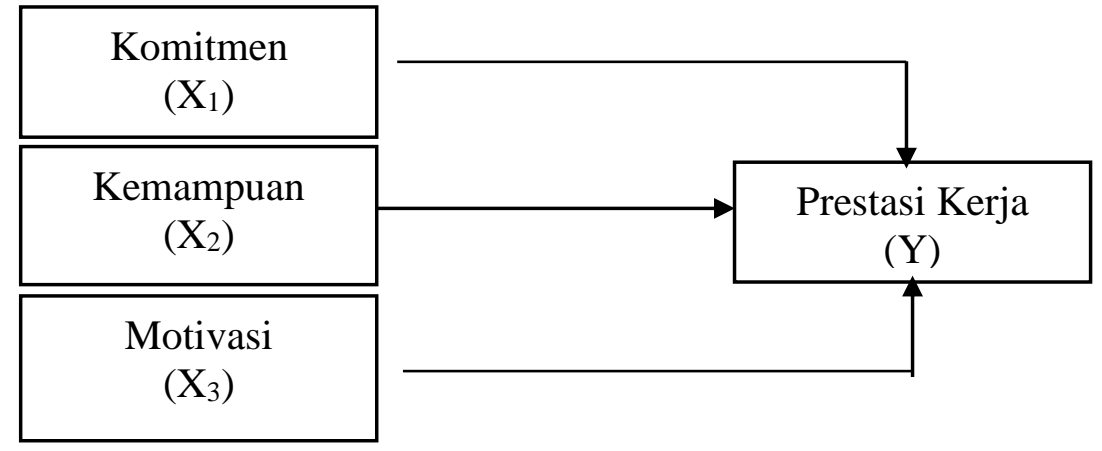

Gambar 1

Kerangka Konseptual

\section{METODE PENELITIAN \\ Jenis dan Sumber data}

Riset yang dilakukan termasuk dalam jenis riset lapangan, (field research) yakni riset yang dilaksanakan pada keadaan yang sebenarnya terjadi. Kemudian, peneliti juga menjalankan studi mengenai pustaka penelitian (library research) yang akan 
menyempurnakan serta memberikan kelengkapan mengenai data dalam riset ini. Adapun menurut sifatnya dikategorikan pada riset asosiatif, dimana riset ini menunjukkan ada tidaknya dampak yang signifikan pada komitmen, kemampuan serta motivasi pada prestasi bekerja Pegawai Kantor Desa pada Selat Akar Kecamatan Tasik Putri Puyu. Serta penelitian ini termasuk dalam pendekatan kuantitatif.

\section{Populasi dan Sampel}

Populasi adalah subjek ataupun objek yang terdapat pada satu lokasi serta sesuai dengan kriteria tertentu yang selaras pada problem dalam riset. Populasi pada riset ini berjumlah sebesar 31 Pegawai Kantor Desa pada Selat Akar Kecamatan Tasik Putri Puyu, serta sampel yang dipilih berjumlah 30 orang.

\section{Analisis Regresi Berganda}

Analisa Teknik analisis data pada riset ini menggunakan Analisis regresi linier berganda yang dimaksudkan dapat melihat bagaimana dampak yang tercipta antara variabel independen pada variabel dependen. Persamaan regresi berganda pada riset ini yakni :

$$
\mathrm{Y}=\mathrm{a}+\mathrm{b} 1 \mathrm{X} 1+\mathrm{b} 2 \mathrm{X} 2+\mathrm{b} 3 \mathrm{X} 3+\mathrm{e}
$$

Dimana:

Y : Variabel terikat (prestasi kerja kerja)

a : Konstanta

b1,b2: Koefisien regresi

$\mathrm{X} 1$ : Variabel bebas (komitmen)

X2 : Variabel bebas (kemampuan)

X3 : Variabel bebas (motivasi)

e : Standard error

\section{HASIL DAN PEMBAHASAN Analisis Regresi Linier Berganda}

Analisis regresi linier secara berganda dilaksanakan guna menentukan dampak variabel komitmen, kemampuan serta motivasi kerja pada prestasi bekerja aparat Kantor Desa Selat Akar. Tujuan mencari tahu dampak variabel komitmen, kemampuan serta motivasi kerja pada prestasi bekerja aparat mampu diamati pada temuan analisayang diolah dengan SPSS 25.00 pada tampilan berikut.

Tabel 1

Hasil Analisis Regresi Linier Berganda

\begin{tabular}{|c|c|c|c|}
\hline \multirow[t]{2}{*}{ Model } & \multicolumn{2}{|c|}{$\begin{array}{c}\text { Unstandardized } \\
\text { Coefficients }\end{array}$} & \multirow{2}{*}{$\begin{array}{c}\text { Standardized } \\
\text { Coefficients } \\
\text { Beta }\end{array}$} \\
\hline & $\mathrm{B}$ & Std. Error & \\
\hline (Constant) & 1.075 & 0.482 & \\
\hline Komitmen & 0.093 & 0.148 & 0.123 \\
\hline Kemampuan & 0.272 & 0.166 & 0.319 \\
\hline Motivasi & 0.452 & 0.100 & 0.591 \\
\hline
\end{tabular}

Sumber: Hasil Analisis Data, diolah, 2021.

Model matematik regresi linier berganda terbentuk yakni:

$\mathrm{Y}=1.712+0.414 \mathrm{X} 1+0.396 \mathrm{X} 2+$ $0.613 \mathrm{X} 3$

Didasarkan model regresi yang tercipta di atas, dapat dimaknai dari koefisien di tiap-tiap variabel yang tercipta yakni, $\mathrm{A}=$ Konstanta bernilai 1.712 yang bermakna bahwa variabel komitmen, kemampuan dan motivasi dianggap konstan maka prestasi kerja aparat Kantor Desa Selat Akar 
akan positif. Kemudian b1 $=0.093$, koefisien pada regresi komitmen bernilai 0.093 kemudian memiliki makna jika kemampuan aparat dan motivasi kerja konstan, maka dengan adanya peningkatan komitmen aparat hingga berdampak pada prestasi kerja aparat Kantor Desa Selat Akar meningkat. Kemudian b2 $=0.272$, koefisien regresi kemampuan bernilai 0.272 yang bermakna jika komitmen serta motivasi aparat tetap, maka apabila terjadi penambahan pada kemampuan aparat mampu berdampak pada prestasi bekerja aparat Kantor Desa Selat Akar meningkat. Kemudian b3 $=0.452$, koefisien regresi motivasi bernilai 0.452 yang bermakna jika komitmen serta kemampuan aparat tetap, maka apabila terjadi penambahan pada motivasi aparat mampu berdampak pada prestasi bekerja aparat Kantor Desa Selat Akar meningkat.

\section{Uji t (Parsial)}

Uji $t$ ataupun uji parsial dilaksanakan untuk mengetahui tingkat signifikan dampak komitmen, kemampuan serta motivasi aparat pada Prestasi Kerja Aparat di Kantor Desa Selat Akar dari tiap-tiap variabel. Temuan analisis uji t dengan bantuan program SPSS versi 25.00 dapat diamati pada hasil berikut.

Tabel 2

Uji-t (Parsial)

\begin{tabular}{llll}
\hline & Model & $\mathrm{t}$ & Sig. \\
\hline 1 & (Constant) & 2.229 & 0.035 \\
& Komitmen & 0.624 & 0.538 \\
& Kemampuan & 1.640 & 0. \\
& Motivasi & 4.537 & 0.000 \\
\hline
\end{tabular}

Sumber: Data primer, diolah, 2021.

Bersumber perhitungan tersebut diperoleh hasil dari thitung $=0.624$ dengan nilai significant sebesar 0.538 , maka H1 "ditolak" serta Ho "diterima" yang kemdian diartikan tidak ada dampak signifikan variabel komitmen pada variabel prestasi kerja aparat Kantor Desa Selat Akar. Didasarkan temuan serta analisa dapat disimpulkan jika hipotesis pertama dengan pernyataan "Terdapat pengaruh yang signifikan antara komitmen terhadap prestasi kerja Aparat Kantor Desa Selat Akar Kecamatan Tasik Putri Puyu" tidak terbukti kebenarannya.

Ho : Tidak ada pengaruh signifikan variabel komitmen terhadap variabel prestasi kerja aparat.
H1 : Ada pengaruh signifikan variabel komitmen terhadap variabel prestasi kerja aparat.

Berdasarkan proses olah data yang telah dilakukan didaptkan temuan pada thitung $=1.640$ dengan nilai significant sebesar 0.030 , maka Ho "ditolak" serta H1 "diterima" dan dapat disimpulkan jika ada dampak signifikan variabel kemampuan pada variabel prestasi kerja aparat Kantor Desa Selat Akar. Didasarkan temuan analisa ini menggambarkan bahwa hipotesis kedua yang berbunyi "Terdapat pengaruh yang signifikan antara kemampuan terhadap prestasi kerja Aparat Kantor Desa Selat Akar Kecamatan Tasik Putri Puyu" terbukti kebenarannya. 
Hipotesis kedua, pengaruh variabel komunikasi pada kinerja pegawai

Ho : Tidak ada pengaruh signifikan variabel kemampuan terhadap variabel prestasi kerja aparat.

H1 : Ada pengaruh signifikan variabel kemampuan terhadap variabel prestasi kerja aparat.

Berdasarkan proses olah data yang telah dilakukan didaptkan temuan pada thitung $=4.537$ dengan nilai significant sebesar 0.000 , maka Ho "ditolak" serta H1 "diterima" dan dapat disimpulkan jika ada dampak signifikan variabel motivasi pada variabel prestasi kerja aparat Kantor Desa Selat Akar. Didasarkan temuan analisa ini menggambarkan bahwa hipotesis kedua yang berbunyi "Terdapat pengaruh yang signifikan antara motivasi terhadap prestasi kerja Aparat Kantor Desa Selat Akar Kecamatan Tasik Putri Puyu" terbukti kebenarannya.

Hipotesis ketiga, dampak variabel motivasi kerja pada hasil kerja staff.
Ho : Motivasi kerja berpengaruh negatif tidak signifikan terhadap kinerja pegawai Kantor Sekretariat DPRD Kabupaten Kepulauan Meranti Bagian Humas dan Protokoler Kabupaten Kepulauan Meranti
H1 : Motivasi kerja berpengaruh positif signifikan terhadap kinerja pegawai Kantor Sekretariat DPRD Kabupaten Kepulauan Meranti Bagian Humas dan Protokoler Kabupaten Kepulauan Meranti Uji Koefisien Determinasi (R2)

Uji koefisien determinasi (R2) dilaksanakan agar diperoleh gambaran mengenai besar variabel komitmen, kemampuan serta motivasi kerja mampu menggambarkan variabel prestasi kerja aparat di Kantor Desa Selat Akar. Nilai R2 berada antara nol sampai satu, jika nilai mendekati 1 bisa diasumsikan model yang ada dalam kategori baik. Temuan analisis uji koefisien determinasi (R2) dapat diamati pada tabel berikut.

Tabel 3

Hasil Uji Koefisien Determinasi $\left(\mathbf{R}^{\mathbf{2}}\right)$

\begin{tabular}{llrrr}
\hline Model & $\mathrm{R}$ & R Square & $\begin{array}{c}\text { Adjusted R } \\
\text { Square }\end{array}$ & $\begin{array}{r}\text { Std. Error of } \\
\text { the Estimate }\end{array}$ \\
\hline 1 & $.757^{\mathrm{a}}$ & .573 & .524 & .30635 \\
\hline
\end{tabular}

Sumber: Data primer, diolah, 2021.

Berdasarkan temuan olah data yang dilakukan didapati nilai koefisien determinasi (R2) sebesar 0.573 , temuan ini memiliki makna jika variabel komitmen, kemampuan dan motivasi kerja dapat menjelaskan variabel prestasi kerja aparat di Kantor Desa Selat Akar sebesar $57.3 \%$ serta $42.7 \%$ dijabarkan oleh faktor maupun variabel lainnya di luar model pada riset ini.

\section{Pembahasan}

Didasarkan temuan analisis riset yang dilaksanakan serta memakai persamaan model regresi linier berganda dapat menjelaskan bahwa tidak terdapat dampak signifikan variabel komitmen pada variabel prestasi bekerja aparat di Kantor Desa Selat Akar, ini dapat berarti bahwa jika variabel komitmen semakin baik, maka Prestasi Kerja Aparat di Kantor 
Desa Selat Akar tidak akan semakin baik juga tetapi juga tidak akan menjadi tidak baik karena arahnya masih positif. Bersumber temuan penelitian menggambarkan jika ada ketidaksamaan pada riset sebelumnya yang dilaksanakan oleh Sukmana serta Adinegara (2018:277) menunjukkan jika keterikatan/komitmen organisasional berdampak pada prestasi bekerja pegawai. Begitu juga temuan riset Syukriadi et. al (2019:1) yang menunjukkan bahwa keterikatan/komitmen organisasi berdampak pada prestasi bekerja pada Kemenag Kabupaten Bulukumba. Hal tersebut dapat disebabkan karena Aparat Kantor Desa Selat Akar tidak sepenuhnya merasa bangga karena telah menjadi bagian dari Pemerintahan Kantor Desa Selat Akar dan juga tidak sepenuhnya merasa bahwa dengan bekerja di Kantor Desa Selat Akar tersebut telah menjadi bagian dalam hidupnya. Meskipun demikian keinginan Aparat Kantor Desa untuk mengusahakan agar kepentingan Kantor Desa dapat tercapai karena mempunyai angka rerata yang tertinggi dibandingkan item pernyataan yang diajukan lainnya. Dengan demikian aparat Kantor Desa harus lebih meningkatkan keinginannya dalam mengusahakan kepentingan Kantor Desa. Aparat yang memiliki keterikatan/komitmen organisasi yang besar yang menjadikan pegawai yang memiliki kecakapan saing besar dalam menghasilkan segala upaya serta kinerja yang dimiliki secara optimal dalam rangka mewujudkan target organisasi.

Berdasarkan hasil analisis dapat dijelaskan terdapat dampak signifikan variabel kemampuan pada variabel prestasi bekerja aparat di Kantor Desa Selat Akar, ini dapat berarti bahwa jika variabel kemampuan semakin baik, maka akan meningkatkan Prestasi Kerja Aparat di Kantor Desa Selat Akar dengan peningkatan yang signifikan. Pada temuan penelitian yang ada menggambarkan jika terdapat persamaan pada riset sebelumnya yang dilaksanakan oleh Driyono et. al (2019:66) menunjukkan bahwa variabel kemampuan berpengaruh signifikan terhadap prestasi kerja pegawai. Begitu juga hasil penelitian Arif (2020:106) yang menunjukkan bahwa Kemampuan Kerja berpengaruh signifikan pada prestasi bekerja pegawai. Kemudian jika dilihat dari hasil kuesioner, diketahui bahwa ratarata Aparat Kantor Desa Selat Akar sudah merasa memiliki kemampuan dalam menyelesaikan pekerjaan yang diberikan kepadanya sesuai dengan target yang telah ditentukan sebelumnya. Aparat Kantor Desa Selat Akar juga berkeinginan untuk mempertahankan statusnya sebagai Aparat Kantor Desa dapat meningkatkan penguasaan teori dan ketrampilan dalam memberikan berbagai keputusan terhadap persoalan yang menyangkut kegiatan mencapai tujuan. Kemudian Aparat Kantor Desa dengan masa kerja yang lama belum tentu memiliki kemampuan untuk menyelesaiakan pekerjaan lebih baik dari pada yang belum lama bekerja di Kantor Selat Akar. Jadi pegawai yang belum lama bekerja di Kantor Desa Selat Akar dapat cepat beradaptasi dengan beban kerja yang diberikan kepadanya.

Dari temuan penelitian didapatkan jika terdapat dampak signifikan variabel motivasi pada 
variabel prestasi bekerja aparat di Kantor Desa Selat Akar, ini dapat berarti bahwa jika variabel motivasi kerja semakin baik, maka akan meningkatkan Prestasi Kerja Aparat di Kantor Desa Selat Akar dengan peningkatan yang signifikan. Pada temuan penelitian yang ada menggambarkan jika terdapat persamaan pada riset sebelumnya yang dilaksanakan oleh Syukriyadi et. al (2019:20) menunjukkan bahwa motivasi bekerja karyawan berdampak positif dan signifikan pada prestasi bekerja di Kemenag Kabupaten Bulukumba. Begitu juga hasil penelitian Driyono et al (2019:66) yang menggambarkan jika motivasi berdampak signifikan pada prestasi bekerja karyawan. Kemudian jika dilihat dari hasil kuesioner, diketahui bahwa Aparat Kantor Desa Selat Akar sudah berusaha semaksimal mungkin dalam melaksanakan pekerjaan dengan sebaik-baiknya oleh sebab itu Aparat Kantor Desa juga memiliki keinginan untuk mendapatkan upah yang adil berdasar pada tanggung jawab pekerjaan yang sebelumnya telah dilakukan.

\section{SIMPULAN DAN SARAN Simpulan}

Berdasar pada temuan analisis data yang mengaplikasikan analisis regresi linier berganda, hingga mampu disimpulkan:

1. Komitmen dan kemampuan kerja aparat dalam kondisi cukup baik, sedangkan motivasi dan Prestasi Kerja Aparat di Kantor Desa Selat Akar dalam kondisi baik.

2. Tidak ada pengaruh yang signifikan diantara komitmen pada prestasi bekerja Aparat Kantor
Desa Selat Akar Kecamatan Tasik Putri Puyu.

3. Terdapat pengaruh yang signifikan diantara kemampuan pada prestasi bekerja Aparat Kantor Desa Selat Akar Kecamatan Tasik Putri Puyu.

4. Terdapat pengaruh $\mathrm{k}$ yang signifikan diantara motivasi pada prestasi bekerja Aparat Kantor Desa Selat Akar Kecamatan Tasik Putri Puyu.

\section{Saran}

Berdasarkan kesimpulan dalam penelitian ini sesuai dengan apa yang ditanayakan dalam rumusan masalah, maka dapat diberikan berbagai saran kepada Kantor Desa Selat Akar dengan cara sebagai berikut:

1. Motivasi kerja perlu mendapat perhatian lebih untuk ditingkatkan karena pada riset ini motivasi memiliki dampak yang paling signifikan pada Prestasi Kerja Aparat Kantor Desa Selat Akar. Dengan lebih memperhatikan pemberian upah sesuai dengan tanggung jawab pekerjaan yang dilakukan agar Aparat Kantor Desa Selat Akar dapat bekerja lebih maksimal lagi dalam melaksanakan pekerjaan dengan sebaik-baiknya.

2. Selain itu, kemampuan juga perlu mendapat perhatian karena kemampuan juga memiliki dampak yang signifikan pada Prestasi Bekerja Aparat Kantor Desa Selat Akar. Aparat yang belum lama bekerja di Kantor Desa Selat Akar perlu dilakukan bimbingan dan arahan agar pekerjaan yang dilakukan dapat lebih terarah dengan baik terutama pada penguasaan teori dan ketrampilan dalam memberikan berbagai keputusan terhadap persoalan yang terjadi. 
3. Pada komitmen Aparat Kantor Desa Selat Akar karena tidak mempunyai pengaruh yang signifikan, oleh karena itu diperlukan penanaman dan pemahaman kepada arapat agar mereka merasa bangga karena telah menjadi bagian dari Pemerintahan Kantor Desa Selat Akar sehingga dalam bekerja apparat dapat bekerja seperti pekerjaan tersebut menjadi bagian dalam hidupnya

\section{DAFTAR PUSTAKA}

Arif Muhammad, Taufik Maulana dan Lesmana Muhammad Taufik, 2020, Pengaruh Disiplin Kerja dan Kemampuan Kerja Terhadap Prestasi Kerja Karyawan, Humaniora, Vol.4, No. 1, April 2020 : 106-119

Driyono Bambang, Imaduddin dan Basalamah Jafar, 2019, Pengaruh Kemampuan dan Motivasi terhadap Prestasi Kerja Pegawai pada Unit Perawatan Pesawat Udara di STPI Curug, paradoks : jurnal ilmu ekonomi Volume 2. No. 3 (2019); Juli

Gibson, 2017, Organization, Behavior, Structure \& Process, edition 10, Boston.USA

Hasibuan Malayu S.P., 2017, Manajemen Sumber Daya Manusia, Edisi Revisi, Jakarta: Bumi Aksara.

Mangkunegara AA. Anwar Prabu, 2017, Manajemen Sumber Daya Manusia, Bandung: Remaja Rosdakarya
Nawawi Hadari, 2016, Manajemen Sumber Daya Manusia, Yogyakarta: Gadjah Mada.

Prasetyo, Indra; Aliyyah, Nabilah; Rusdiyanto; Utari, Woro; Suprapti, Sri; Kartika, Chandra; Winarko, Ruddy; Chamariyah; Panglipursari, Dwi Lesno; Muninghar, Halimah, Nur; Aminatuzzuhro; Indrawati, Mei; Junus, Onong: Herli, Mohammad; Hafidhah; Kustiningsih, Nanik; Gazali; Kusuma, Adriani; Aina, Muslimatul; Bustaram, Isnain; Risal, Zef; Zainurrafiqi; Amar, Siti Salama; Umah, Khoiroh; Khadijah, Susan Novitasari; Gustomi, Mono Pratiko; Irawan, Hendra; Rochman, Arif Syafi'ur; Pramitasari, Dini Ayu; Farid, Muhammad Miftah; Kalbuana, Nawang. 2021. Effects of Organizational Communication Climate and Employee Retention Toward Employee Performance. Journal of Legal, Ethical and Regulatory. Vol: 24 Issue: $1 \mathrm{~S}$ (2021)

Rivai Veithzal Zainal S., 2015, Manajemen Sumber Daya Manusia Untuk Perusahaan . Edisi ke-7. Depok: PT Rajagrafindo

Robbins P. Stephen \& Coutler Mary, 2016, Human Resources Management, Edisi 16, Jilid 1, Jakarta: Salemba Empat

Robbins Stephen, 2015, Perilaku Organisasi, Jakarta: Penerbit Salemba Empat 
Sukmana Teja dan Adinegara Gusti

Ngurah Joko, 2018, Analisis

Komitmen Organisasional

Terhadap Prestasi Kerja

Karyawan Grand Inna Kuta

Bali, Prosiding Sintesa, 2

November 2018

Sutrisno Edy, 2017, Manajemen

Sumber Daya Manusia, Jakarta:

Kencana,

Syakur, Abd.; Utari, Woro; Chamariyah. Correlation between Organizational Roles, OBC, and Organizational Commitment toward Employees of the Limited Liability Company of State Electricity Company of APJ Jember. 2021. Budapest International Research and Critics Institute (BIRCIJournal) : Humanities. Vol 4, No 2 (2021)

Syukriadi, Pananrangi Rasyid dan Azis Mansur, Pengaruh Komitmen Organisasi dan Diklat Terhadap Prestasi Kerja Melalui Motivasi Kerja Pegawai di Kementerian Agama Kabupaten Bulukumba, YUME : Journal of Management Volume2 No. 12019

Usman, Firmansyah, 2019, Pengaruh lingkungan kerja dan kompensasi serta komitmen organisasi terhadap kepuasan dan prestasi kerja pegawai, Jurnal Manajemen - Vol. 11 (2) 2019, 123-142

Utari, Woro; Iswoyo, Andi; Chamariyah; Mardiana, Fitra; Hidayat, Widi; Waras;
Rusdiyanto. 2021. Effect Of Work Training, Competency and Job Satisfaction on Employee Productivity: A Case Study Indonesi. Review Of International Geographical Education. 11(4), Winter, (2021)

Utari, Woro; Setiawati, Ratna; and Fauzia, Nur. 2020. The Effect of Work Discipline on the Performance of Employees in Compensation Mediation: A Case Study Indonesia. PalArch's Journal of Archaeology of Egypt/Egyptology 17 (9) (2020) 